\title{
Blasts 0 Percent of Peripheral Blood White Cells
}

National Cancer Institute

\section{Source}

National Cancer Institute. Blasts O Percent of Peripheral Blood White Cells. NCI

Thesaurus. Code C154093.

A semi-quantitative microscopic finding indicating that immature mononuclear cells are not detected when the nucleated cells in a peripheral leukocyte sample were examined. 